International Journal of Economics, Business and Accounting Research (IJEBAR)

Peer Reviewed - International Journal

Vol-4, Issue-2, 2020 (IJEBAR)

E-ISSN: 2614-1280 P-ISSN 2622-4771

https://jurnal.stie-aas.ac.id/index.php/IJEBAR

\title{
Fiscal Regency And City Capacity In East Kalimantan In The Era OF REgional AUTONOMY
}

\author{
Soeharjoto1, Debbie Aryani Tribudhi2, Lucky Nugrohoz \\ Universitas Trisakti1,2, Jakarta, Indonesia \\ Universitas Mercu Buana3, Jakarta, Indonesia \\ Email:1soeharjoto@trisakti.ac.id \\ 2debbie.aryani@trisakti.ac.id \\ 3lucky.nugroho@mercubuana.ac.id
}

\begin{abstract}
This study aims to determine the fiscal decentralization capacity of regencies and cities in East Kalimantan Province by referring to the map of blood financial capability using share index and growth indicators, regional decentralization indices, and regional independence index. The results of the City of Balikpapan, Samarinda City, Bontang City, and Berau Regency are areas that can be considered feasible in the implementation of fiscal autonomy. Other regions are not feasible. In fact, in the long run, there will be obstacles because regions that are considered worthy of fiscal autonomy rely on non-renewable natural resources, so that human resource development is needed to be able to move into the natural resource processing sector that can be updated and services.
\end{abstract}

Keywords: $\quad$ Regency and City Share and Growth Index, Regional Decentralization Index and Independence Index

\section{Introduction}

The implementation of regional autonomy was carried out by the post-independence government, later the New Order government changed the decentralization policy into centralization. Finally, in the Reform Order government I changed the policy back to decentralization, because centralization was considered to hinder development.Decentralization is carried out with the aim of accelerating regional independence (Soeharjoto, 2019). This policy, is expected to have a fundamental impact on increasing Regional Original Income (PAD), because local governments can innovate (Soekapdjo, 2018). However, what happened was just the opposite, even the increasing fiscal dependence of the regional government on the center. It shows helplessness PAD to finance their spending. The PAD should be used for regional expenditures, which are allocated in regional expenditures, carried out fairly and evenly without discrimination, for public services. All of them are inseparable from the diverse conditions in Indonesia (Soekapdjo, 2019).

At the beginning, Kalimantan is a province divided into East Kalimantan, South Kalimantan, Central Kalimantan and West Kalimantan. The development of decentralization in Kalimantan is quite good, as evidenced by the expansion of its territory, with the formation of North Kalimantan, on October 25, 2012. 
International Journal of Economics, Business and Accounting Research (IJEBAR)

Peer Reviewed - International Journal

Vol-4, Issue-2, 2020 (IJEBAR)

E-ISSN: 2614-1280 P-ISSN 2622-4771

https://jurnal.stie-aas.ac.id/index.php/IJEBAR

Reliable human resources (HR) are needed in the era of regional autonomy. A high Human Development Index (HDI) is an indicator of the quality of human resources in a region. Kalimantan Province has a diverse quality of human resources. The average HDI in the Kalimantan region in 2013-2017 was 69.074 percent. East Kalimantan (74.18 percent) is an area where the HDI is above average and other regions HDI is still below, namely, North Kalimantan (68.90 percent), Central Kalimantan (68.53 percent), South Kalimantan (68.38 percent), and West Kalimantan (65.38 percent).

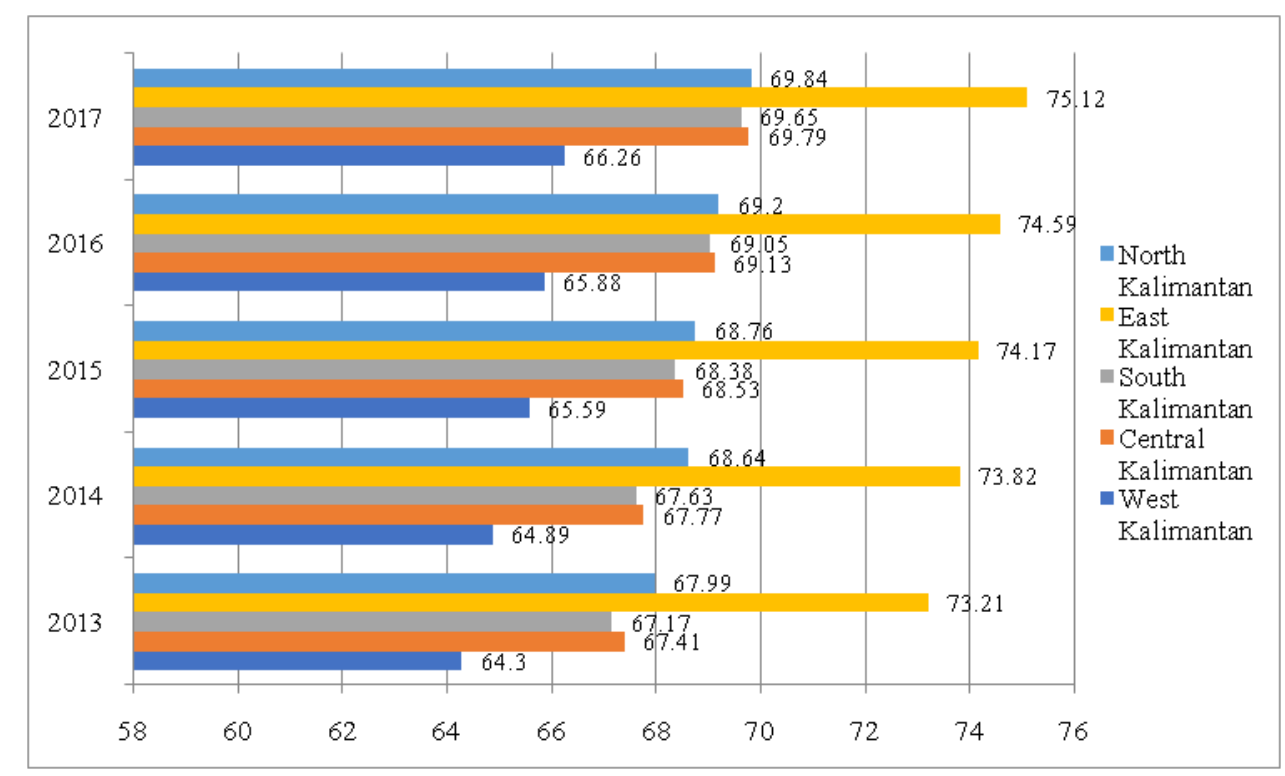

Figure 1. HDI in Kalimantan Province, In 2013-2017 (Percent) Source: BPS

Rostow (1959), in his theory of development, linked the development of government spending to the stages of economic development. In the initial stages of economic development, the government needs to make a large investment, because it provides facilities and community services. In the middle stage, for development to occur, government investment is still needed, which is balanced with private investment, but if the role of the private sector is too large there will be a market failure. In the later stages, government activities will shift to using funds to provide facilities and infrastructure for social activities. Wagner (1893), revealed a tendency for increased government spending. Government will always try to increase its expenditure by increasing tax revenues, but actually with an increase in taxes will be followed by an increase in government spending (Peacock and Wisemen, 1961). The government does expenditure to carry out its functions as allocation, distribution and stabilization (Musgrave, 1969).

In agency theory, agents in regional governments will behave as if they will maximize service to the middle and lower societies (Holtz-Eakin et al ., 1994). That is, agents will allocate resources based on their expectations of the economic environment in the future. As for the assumption, all expenditures depend on existing resources (balance budget rule). 
International Journal of Economics, Business and Accounting Research (IJEBAR)

Peer Reviewed - International Journal

Vol-4, Issue-2, 2020 (IJEBAR)

E-ISSN: 2614-1280 P-ISSN 2622-4771

https://jurnal.stie-aas.ac.id/index.php/IJEBAR

Communities that obtain public services and good welfare are a reflection of the success of decentralization. For this reason, a number of funds are needed for the financing. The procedure is carried out by carrying out fiscal decentralization through reform from the expenditure side and then the regional revenue side.

Haryanto (2017), with regional Financial Mapping, found that in general the regions producing natural resources have high regional independence, but the future economic growth will be low, but non-natural resource regions have low regional independence but future economic growth will be high. Regional financial mapping conducted by Hidayat, et al., (2016), revealed that in general the regions experienced an increase in PAD growth but were not followed by an increase in PAD Share on regional expenditure, which indicated that regional dependence was still high in the central government. Basri et al., (2013), with a mapping of PAD performance, it was found that the average growth of PAD of Districts and Cities in Jambi Province was 18.48 percent with an average contribution of 6.33 percent. Samora (2010), in its mapping reveals that regional autonomy has not succeeded in creating independence, because 72 percent of districts and cities in Java and Bali are still classified as non-independent regions.

The degree of decentralization index conducted by Kamaroellah (2017), shows the degree of decentralization in Pamekasan District is very lacking because its independence or financial capacity in implementing regional autonomy is relatively low. Risyanto (2015), in the decentralization degree index shows that Garut Regency still relies on financial sources originating from outside the PAD.

The regional independence index conducted by Kamaroellah (2017), revealed that Pamekasan Regency was in the instructive category. Risyanto (2015), in the index of independence of the region in Garut Regency is in the instructive category.

The index and fiscal decentralization have the effect of increasing regional authority in obtaining funds to finance its development. Diverse human resources and natural resources will have an impact on the region's ability to manage its fiscal.

East Kalimantan has superior natural resources and human resources which will have an impact on fiscal decentralization readiness. Superior District and City potential can be used as an example to motivate other regions. For the success of regional autonomy in East Kalimantan, it is necessary to research the decentralized fiscal capacity of districts and cities.

\section{Research Method}

Capability maps, independence, and the degree of financial decentralization in the districts and cities in East Kalimantan Province, in 2013-2017, used descriptive methods. The data used to come from the Directorate General of Fiscal Balance (DGTK), Ministry of Finance of the Republic of Indonesia.

A map of regional financial capacity is a general description of the ability of regional finance in implementing regional autonomy. The formula used is:

$$
\begin{gathered}
\text { Share }=\frac{\text { Locally }- \text { Generated Revenue }}{\text { Total Shopping }} \times 100 \% \\
\text { Growth }=\frac{\text { Locally }- \text { Generated Revenue }(\mathrm{t})}{\text { Locally-Generated Revenue }(\mathrm{t}-1)} \times 100 \%
\end{gathered}
$$


International Journal of Economics, Business and Accounting Research (IJEBAR)

Peer Reviewed - International Journal

Vol-4, Issue-2, 2020 (IJEBAR)

E-ISSN: 2614-1280 P-ISSN 2622-4771

https://jurnal.stie-aas.ac.id/index.php/IJEBAR

Making a map of regional financial capacity is done by classifying it into four parts (BAPPENAS, 2003). The classification is:

- Quadrant1: The ideal condition, because PAD has a large role in the regional budget and the regions have the ability to develop local potential.

- Quadrant 2: The conditions are not ideal, because even though the regions have the ability to develop local potential, the contribution of PAD to the regional budget is still low.

- Quadrant 3: Conditions are not ideal, though PAD have a major contribution in the regional budget, but PAD growth is small.

- Quadrant 4: Conditions are not ideal because PAD does not have a large role in the regional budget and have not been able to develop local potential.

The Regional Independence Index is conducted to determine the dependence of regional governments on sources of funds from the central government. The formulas are:

$$
\text { Regional Independence Index }=\frac{\text { Locally-Generated Revenue }}{\text { Consideration Fund }} \text { X } 100
$$

Regional independence has indicators by classifying into four parts (Kepmendagri No. 690.9000.327 Year 1996). The grouping is done in several categories:

- Instructive :Percentage of PAD to Balancing Funds $\leq 25$.

- Consultative :Percentage of PAD to Balancing Funds 20-50.

- Participative :Percentage of PAD to Balancing Funds 51-75.

- Delegative :Percentage of PAD to Balancing Funds 76-100.

Degree of regional decentralization index is the ability of regional governments to increase PAD to finance their development. The formula is:

$$
\text { Regional Decentralization Index }=\frac{\text { Locally }- \text { GeneratedRevenue }}{\text { Total Regional Revenue }} \mathrm{X} 100 \%
$$

Degree of regional decentralization index is grouped into five sections (Research and Development Agency of the Ministry of Home Affairs and FISIPOL-UGM, 1991). The grouping is:

- Very Less $\quad$ : The percentage of PAD to Total Regional Income 00.00-10.00.

- Less $\quad:$ The percentage of PAD to Total Regional Income 10.01-20.00.

- As $\quad$ : The percentage of PAD to Total Regional Income 20.01-30.00.

- Enough : The percentage of PAD to Total Regional Income 30.01-40.01

- Well : The percentage of PAD to Total Regional Income 40.01-50.00

- Very Good : The percentage of PAD to Total Regional Income $>50.01$. 
International Journal of Economics, Business and Accounting Research (IJEBAR)

Peer Reviewed - International Journal

Vol-4, Issue-2, 2020 (IJEBAR)

E-ISSN: 2614-1280 P-ISSN 2622-4771

https://jurnal.stie-aas.ac.id/index.php/IJEBAR

\section{Results and Discussion}

The regional financial capability map shows that there are no districts or cities in East Kalimantan in quadrant 1, but in quadrant 2 (Mahakam ulu Regency, East Kutai Regency, North Penajam Paser Regency), quadrant 3 (Balikpapan City, Samarinda City, Bontang City), and Quadrant 4 (Berau Regency, West Kutai Regency, Kutai Kartanegara Regency, Paser Regency) . As for the means so that this region can develop its own capabilities, need more improved right again PAD growth and more large contribution of PAD to the Regional Budget. The independence of this area is almost entirely in the instructive category and only Kota Balikpapan is in the Constructive category. Most of the degrees of decentralization are in very poor conditions, except Samarinda City, Bontang City, and Berau Regency. Balikpapan City actually has a medium category. Referring to these indicators, in Kalimantan Province has areas that are ready to face regional fiscal autonomy, namely Balikpapan City, Samarinda City, Bontang Regency, and Berau District.

Table 1. Regency and City Share and Growth Index in East Kalimantan Province

\begin{tabular}{l|r|r}
\hline \multicolumn{1}{c|}{ East Kalimantan Province } & \multicolumn{1}{c|}{ Share } & Growth \\
\hline Berau Regency & 9.42 & 6.27 \\
\hline Kutai Kartanegara Regency & 6.82 & 13.93 \\
\hline West Kutai Regency & 5.3 & 17.44 \\
\hline East Kutai Regency & 7.16 & 69.18 \\
\hline Paser Regency & 5.74 & 10.76 \\
\hline Balikpapan City & 25.47 & 10.8 \\
\hline Bontang City & 17.23 & 13.03 \\
\hline Samarinda City & 12.14 & 11.84 \\
\hline North Penajam Paser Regency & 7.84 & 50.51 \\
\hline Mahakam Ulu Regency & 1.25 & 73.87 \\
\hline Source: Resuls of
\end{tabular}

Source: Results of data processed

Indkes share DA and growth obtained, can then be made map dire financial capabilities. The results obtained are:

- Quadrant1:

- Quadrant 2: Mahakam Ulu Regency, East Kutai Regency, North Penajem Paser Regency.

- Quadrant 3: Balikpapan City, Samarin City, Bontang City.

- Quadrant 4: West Kutai Regency, Kutai Kartanegara Regency, Paser Regency, Berau Regency.

There are no districts and cities in East Kalimantan in quadrant 1, meaning that they do not have high share and growth areas. In quadrant 2, there are three districts, which means they have a low but high growth share. Three cities are in quadrant 3, which means they have a high and low growth share. Quadrant 4, there are 4 districts, which mean that they have low and lower growth shares. 
International Journal of Economics, Business and Accounting Research (IJEBAR)

Peer Reviewed - International Journal

Vol-4, Issue-2, 2020 (IJEBAR)

E-ISSN: 2614-1280 P-ISSN 2622-4771

https://jurnal.stie-aas.ac.id/index.php/IJEBAR

The independence index of the regencies and cities in the province of Kalimantan, only Kota has a consultative ability behind it, which means that it is slightly better able to carry out regional autonomy. Other regions are in the instructive category, which means that financially does not have the ability to regional autonomy.

The degree of decentralization index of districts and cities in Kalimantan Province, Balikpapan City has a moderate category, 2 cities and 1 district are in the less category. Other regions fall into a very less category.

\section{Table 2. Regional Decentralization Index and Independence Index of Districts and Cities} in East Kalimantan Province

\begin{tabular}{l|r|r}
\hline \multicolumn{1}{c|}{ East Kalimantan Province } & \multicolumn{1}{c|}{ RDI } & \multicolumn{1}{c}{ RII } \\
\hline Berau Regency & 10.09 & 14.05 \\
\hline Kutai Kartanegara Regency & 7.43 & 9.52 \\
\hline West Kutai Regency & 5.26 & 6.89 \\
\hline East Kutai Regency & 7.22 & 9.98 \\
\hline Paser Regency & 5.85 & 8.77 \\
\hline Balikpapan City & 26.65 & 51.32 \\
\hline Bontang City & 12.11 & 16.91 \\
\hline Samarinda City & 13 & 23.16 \\
\hline North Penajam Paser Regency & 8.11 & 14.97 \\
\hline Mahakam Ulu Regency & 1.72 & 1.47 \\
\hline Source: Results of data processed &
\end{tabular}

East Kalimantan Province has several City and Regency areas that are ready to carry out regional fiscal autonomy. Balikpapan City is an area that was used as the oil refinery center of PT. Pertamina to manage oil from Libya, Saudi Arabia, Nigeria and Brunei Darussalam. Samarinda City is an area that is the capital of East Kalimantan Province. Bontang Regency is the area where 2 large companies are located, I believe Pupuk Kaltim and PT. L NG Rhinoceros, which is the largest gas producer in the world. Berau regency made in place of tourist attraction.

\section{Conclusion}

The regional financial capability map shows that there are no districts or cities in East Kalimantan in quadrant 1, but in quadrant 2 (Mahakam ulu Regency, East Kutai Regency, North Penajam Paser Regency), quadrant 3 (Balikpapan City, Samarinda City, Bontang City), and Quadrant 4 (Berau Regency, West Kutai Regency, Kutai Kartanegara Regency, Paser Regency). As for the means so that this region can develop its own capabilities, need more dingkat right again PAD growth and more large contribution of PAD to the regional budget. The independence of this area is almost entirely in the instructive category and only Balikpapan City is in the Constructive category. Most of the degrees of decentralization are in very poor conditions, except Samarinda City, Bontang City, and Berau Regency. Balikpapan City actually has a medium category. Referring to these indicators, in Kalimantan Province has areas that are 
International Journal of Economics, Business and Accounting Research (IJEBAR)

Peer Reviewed - International Journal

Vol-4, Issue-2, 2020 (IJEBAR)

E-ISSN: 2614-1280 P-ISSN 2622-4771

https://jurnal.stie-aas.ac.id/index.php/IJEBAR

ready to face regional fiscal autonomy, namely Balikpapan City, Samarinda City, Bontang Regency, and BerauRegency District.

East Kalimantan Province in the face of regional fiscal autonomy is still not ready, especially for the long term. It can be said that because of several cities and regencies which felt that fiscal autonomy was quite good, it turned out that they still relied on natural resource management. To anticipate the long-term capacity of human resources needs to be increased by more work on the natural resource processing sector which can be updated and services. Berau Regency can be used as an example for the development of other tourism areas, but the standard needs to be increased so that it can be of international scale.

\section{References}

Basri, H., Syaparuddin, S., \& Junaidi, J. (2013). Regional Original Revenue Performance Mapping and Financial Capability of Regency/City Regions in Jambi Province. Journal of Regional Finance and Development Perspective, 1(2), 81-90.

BAPPENAS. (2003). Map of Provincial Financial Capabilities in the Era of Regional Autonomy: Overview of PAD Performance and Efforts Made by Regions. Directorate of Regional Autonomy Development.

Badan Litbang Depdagri RI dan FISIPOL-UGM. (1991). Measurement of Level II Regional Financial Capabilities within a Real and Responsible Regional Autonomy Framework Jakarta.

Depdagri. (2017). Kepmendagri No. 690.9000.327 Tahun 1996 about Financial Assessment and Performance Guidelines

Haryanto, J. T. (2017). Comparative Analysis of Regional Financial Mapping from The Producer of Natural Resources and Non-Natural Resources in The Fiscal Decentralization Era. Jurnal Ekonomi Dan Kebijakan Publik, 8(2), 103116.DOI: https://doi.org/10.21787/jbp.09.2017.171-184

Hidayat, M., Hadi, M. F., \& Widiarsih, D. (2016). Analysis of Regency / City Financial

Capabilities in West Sumatra Province in the Era of Regional Autonomy. SungkaiJournal 4(2), 36-55. DOI: http://dx.doi.org/10.30606/js.v4i2.1035

Holtz-Eakin, D., Rosen, H. S., \& Tilly, S. (1994). Intertemporal Analysis of State and Local Government Spending: Theory and tests. In Journal of Urban Economics, 35(2), 159-174.

Kamaroellah, R. (2017). Analysis of the Level of Regional Financial Capabilities in Supporting the Implementation of Regional Autonomy. Journal of Islamic Social and Religious Sciences $\quad$ Research, 14(1), 123-138. DOI: http://dx.doi.org/10.19105/nuansa.v14i1.1316

Musgrave, R. A. (1969). Cost-Benefit Analysis and the Theory of Public Finance. Journal of Economic Literature, 7(3), 797-806.

Peacock, A. T., Wiseman, J. (1961). The Growth of Public Expenditure in the United Kingdom, London: Oxford University Press.

Risyanto, H. (2015). Analysis of Regional Financial Capability and Regional Financial Independence and Its Effect on Economic Growth in the Regency of Garut years20042013.Coopetition, 6(1), 21-33. 
International Journal of Economics, Business and Accounting Research (IJEBAR)

Peer Reviewed - International Journal

Vol-4, Issue-2, 2020 (IJEBAR)

E-ISSN: 2614-1280 P-ISSN 2622-4771

https://jurnal.stie-aas.ac.id/index.php/IJEBAR

Rostow, W. W. (1959). The Stages of Economic Growth. The EconomicHistory Review,12(1), 116.

Soekapdjo, S., (2019).Potential economic sectors in Samarindacity. INOVASI, 15(2), 180-187. DOI:http://dx.doi.org/10.29264/jinv.v15i2.5134

Soekapdjo, S., (2018). Map of the Regency and City's Regional Treasury in the Province of

Central Java. Journal of Accountancy, Economics and Business Management, 6(2), 240-

248. DOI: https://doi.org/10.30871/jaemb.v6i2.1013

Soeharjoto. (2019). The ability and financial performance of the province of Kalimantan, AKUNTABEL, 15(2). 131-138. DOI: http://dx.doi.org/10.29264/jakt.v15i2.4472

Samora, R. (2010). Map of Regional Financial Capabilities in City and Regency Governments in Java and Bali in 2004-2008: Quadrant Method, .Jurnal Akuntansi Kontemporer, 2(1).

Wagner, A. (1893). Grunlegung der Politischen Okonomie. 3rd ed. Leipzig: C. F. Winter

www.bps.go.id

www.djpk.kemenkeu.go.id 